\title{
Morphological destruction of cultured cells by the attachment of Treponema pallidum
}

\author{
T J FITZGERALD,* L A REPESH,† AND S G OAKES \\ From the Departments of ${ }^{*}$ Medical Microbiology and Immunology, +Biomedical Anatomy, and \\ $¥$ Physiology, School of Medicine, University of Minnesota, Duluth, Minnesota, USA
}

SUMMARY The incubation of Treponema pallidum with rabbit testicular cells, HEP-2 cells, human foreskin cells, rat cardiac cells, and rat skeletal muscle cells caused morphological disruption of these cultured cells. Control preparations of heat-inactivated treponemes, a highspeed supernatant in which treponemes had been pelleted, and culture medium failed to damage the tissue cells, as did viable treponemes when the cells were incubated in inverted Sykes-Moore chambers. Thus, cellular disruption is not associated with soluble treponemal, soluble inflammatory, or soluble testicular constituents but is mediated by the specific attachment of $T$ pallidum. This organism apparently elaborates some type of toxic activity that lyses membranes; this may explain some of the histopathology of syphilitic disease.

\section{Introduction}

Treponema pallidum apparently lacks the potent toxins that many other bacteria possess. ${ }^{12}$ Early in infection relatively large numbers of treponemes are present within infected tissue and yet cause minimal tissue damage. ${ }^{1}$ It has been suggested that $T$ pallidum is rather innocuous and that clinical manifestations are primarily due to host defences such as inflammation and clearance of organisms. ${ }^{3}$ No specific treponemal toxins have yet been identified.

Wright ${ }^{4}$ reported that $T$ pallidum attached to tissue culture cells. Fitzgerald et $a l^{5}$ confirmed this preliminary finding using cells from rabbit testes, which significantly extended the in-vitro survival of the treponemes. In further studies ${ }^{6} T$ pallidum was shown to attach to 19 different cultured cell types and attachment was identical to that in specimens taken from rabbit dermal and testicular infections. Since non-pathogenic treponemes failed to attach to cultured cells, Fitzgerald et $a l^{67}$ suggested that attachment indicated a specific pathogenic factor that was an important part of the disease process. Numerous other reports have described the $T$ pallidum-tissue culture interaction. ${ }^{8}$ Over 40 different types of cultured cells have been tested, and in each case treponemal attachment did not harm the

Address for reprints: Dr T J Fitzgerald, Department of Medical Microbiology and Immunology, School of Medicine, University of Minnesota, Duluth, Minnesota 55812, USA

Accepted for publication 14 September 1981 cultured cells. As many as 50 organisms may be attached per cell and active motility of the organisms retained for 5-7 days. The cells are not morphologically altered and viability remains high. ${ }^{69}$

Repesh et $a^{1011}$ using high concentrations of $T$ pallidum demonstrated destruction of cultured nerve cells from dorsal root ganglia. Cell damage depended on the attachment of viable treponemes. Heatinactivated organisms failed to attach and affect the morphology of the neuronal cells. Similarly, the cells were not damaged by a preparation containing soluble treponemal, soluble inflammatory, and soluble testicular constituents. This paper expands these observations of treponemal toxic activities to other types of cultured cells.

\section{Materials and methods}

\section{TREPONEMA PALLIDUM}

The Nichols strain was passaged intratesticularly in Dutch belt rabbits. Animals were maintained at $18^{\circ} \mathrm{C}$ and given antibiotic-free food and water in unrestricted quantities. Each testis was inoculated wth $1 \times 10^{7}$ to $3 \times 10^{7}$ treponemes. Daily intramuscular injections of cortisone acetate $(6 \mathrm{mg} / \mathrm{kg})$ were given. After a satisfactory orchitis had developed in 9-11 days, the rabbits were killed and the testes removed, minced with scissors, and extracted on a rotary shaker at room temperature in tissue culture medium. This medium (MEM) contained Eagle's minimal essential medium supplemented with $4 \mathrm{mmol} / 1 \mathrm{NaHCO}_{3}, 30 \mathrm{mmol} / 1 \mathrm{HEPES}$ 
(N-2-hydroxy-ethylpiperazine-N-2-ethanesulfonic acid), $1 \mathrm{mmol} / \mathrm{l}$ dithiothreitol, and $10 \%$ heated normal rabbit serum (at $56^{\circ} \mathrm{C}$ for 30 minutes). After extraction for 20-25 minutes, the preparation was centrifuged at $1000 \times g$ for 10 minutes to sediment particulate matter. Treponemes were then centrifuged at $17000 \times g$ for 30 minutes at $4^{\circ} \mathrm{C}$. The high-speed supernatant was removed and the pelleted organisms were resuspended at a concentration of $9 \times 10^{7}$ to $2 \times 10^{8}$ organisms $/ \mathrm{ml}$ in fresh medium.

\section{TISSUE CULTURE CELLS}

Normal rabbit testicular cells were cultured and maintained as described. ${ }^{6}$ HEP- 2 cells and cells from human foreskin (kindly provided by Dr Richard J Ziegler, University of Minnesota) were grown on glass coverslips in Sykes-Moore chambers. ${ }^{12}$ Except for dithiothreitol, the culture medium was identical to that used for treponemal extraction. Experiments using these three cell types were performed at $10-20 \%$ confluency.

Ventricular heart tissues were obtained from 17-day-old rat embryos by the methods of Marvin et al. ${ }^{13}$ Ventricles were placed into M199 medium containing Earle's balanced salts, $15 \%$ horse serum, penicillin, streptomycin, and gentamicin. The tissue was minced with scissors and exposed to four 30-minute incubations in trypsin at $37^{\circ} \mathrm{C}$. The cells were placed in horse serum at $4^{\circ} \mathrm{C}$, centrifuged at $200 \times g$ for eight minutes, washed, resuspended in M199 medium with supplements of glutamine, minimal essential medium vitamin mixture, and dextrose, and incubated in $35-\mathrm{mm}$ plastic culture dishes at $37^{\circ} \mathrm{C}$ in an atmosphere of $5 \%$ carbon dioxide. Culture medium was changed on days 2 and 5 and then weekly.

Skeletal muscle tissues, obtained from pectoral muscles of 11-day-old rat embryos by the methods of Fischbach, ${ }^{14}$ were cut with scissors, added to trypsin, and incubated at $37^{\circ} \mathrm{C}$ for 30 minutes. Cells were centrifuged at $200 \times g$ for eight minutes and resuspended in culture medium containing Eagle's minimal essential medium supplemented with $600 \mathrm{mg} \%$ glucose, $2 \%$ chick embryo extract, $10 \%$ heated horse serum, $10 \%$ fetal bovine serum, and gentamicin. Approximately $10^{6}$ cells in $3 \mathrm{ml}$ were placed in $60-\mathrm{mm}$ plastic culture dishes. After incubation for $30-45$ minutes at $37^{\circ} \mathrm{C}$, cells in suspension were removed, plated in collagen-coated $35-\mathrm{mm}$ dishes, and incubated at $37^{\circ} \mathrm{C}$ in $5 \%$ carbon dioxide. Many of the fibroblasts were eliminated by exposure to $10^{-5} \mathrm{~mol} / \mathrm{l} \mathrm{D}$-arabinofuranosylcytosine for 48 hours on days 2 and 3. This medium was replaced with fresh culture medium without fetal bovine serum and then changed twice weekly. Experiments with heart and skeletal tissues were $\frac{\mathbb{\Phi}}{\widetilde{D}}$
performed at $80-100 \%$ confluency.

The cardiac and skeletal muscles were grown in the $\frac{\bar{c}}{\mathrm{~N}}$. presence of antibiotics. Before the treponemes were added, cells were washed three times with $4 \mathrm{ml}$ of MEM. The five types of cultured cells were incubatedo at $37^{\circ} \mathrm{C}$ in an atmosphere of $2.5 \% 0_{2}, 5 \% \mathrm{CO}_{2}$, and흐 $92.5 \% \mathrm{~N}_{2}$ with the following: viable treponemes and $\overline{\bar{c}}$. heat-inactivated treponemes $\left(56^{\circ} \mathrm{C}\right.$ for 10 minutes), $\mathbb{\otimes}$ both at concentrations of $9 \times 10^{7}$ to $2 \times 10^{8} \mathrm{~N}$ organisms $/ \mathrm{ml}$, the high-speed supernatant obtained ${ }^{\text {s }}$ by pelleting the treponemes at $17000 \times g$ for $30 \vec{\circ}$ minutes, and the MEM. Each experiment was re- $\overrightarrow{\vec{H}}$ peated 3-5 times with treponemes obtained from different animals.

\section{SCANNING ELECTRON MICROSCOPY}

The cultured cells grown as above on glass coverslips:or in plastic Petri dishes were rinsed twice witho Hank's balanced salt solution and fixed in situ with$3 \%$ glutaraldehyde in $0.1 \mathrm{~mol} / 1$ sodium cacodylate buffer $(\mathrm{pH} \mathrm{7.35)}$ at room temperature for one hour.음 After being rinsed three times with $5 \mathrm{ml}$ of $0.1 \mathrm{~mol} / \mathrm{l}$ sodium cacodylate buffer containing $7 \cdot 5 \%$ sucrose,, the cultures were post-fixed in $1 \%$ osmium tetroxide $\vec{\bullet}$ with $0 \cdot 1 \mathrm{~mol} / 1$ sodium cacodylate for 30 minutes, washed three times in double distilled water, stained in $2 \%$ uranyl acetate and dehydrated in aqueouso grades of alcohol to $100 \%$. The samples on portions of the glass coverslips or the plastic dishes were critical-point dried using $\mathrm{CO}_{2}$, mounted on $\frac{\mathrm{O}}{\mathbb{8}}$ aluminium stubs with double-stick tape, and coated $\varrho$ with gold-palladium using a Hummer II evaporator. $\overrightarrow{\overrightarrow{0}}$ Observations were made with an AMR 1000 scanning electron microscope $(20 \mathrm{kV})$.

\section{Results}

NORMAL RABBIT TESTICULAR CELLS

Normal rabbit testicular cells were incubated inố Sykes-Moore chambers with viable treponemes, heatinactivated treponemes, the high-speed supernatant $\frac{\text { ? }}{5}$ from the infected testes, or MEM. As reported, ${ }^{5} D$ viable treponemes immediately attached to the? cultured cells. Within a few minutes 10-20 organisms, N and within a few hours over 100 organisms, were attached to each cell. As expected, heat-inactivated ${ }^{N}$ treponemes failed to attach. ${ }^{5}$ After 24 hours, all cells exposed to viable organisms showed morphologicalo changes, which became more pronounced after 480 hours (fig 1a). These included excessive vacuolation, $\widetilde{\mathbb{D}}$ loss of nuclear detail, rounded appearance, and $\stackrel{?}{+}$ detachment from the glass substratum. The 0 treponemes became detached from the damaged $\stackrel{\circ}{\circ}$ cells. In contrast, cultured cells exposed to the three $\stackrel{\mathbb{D}}{\mathbb{D}}$ control preparations appeared normal (fig $1 \mathrm{~b}$ ). 

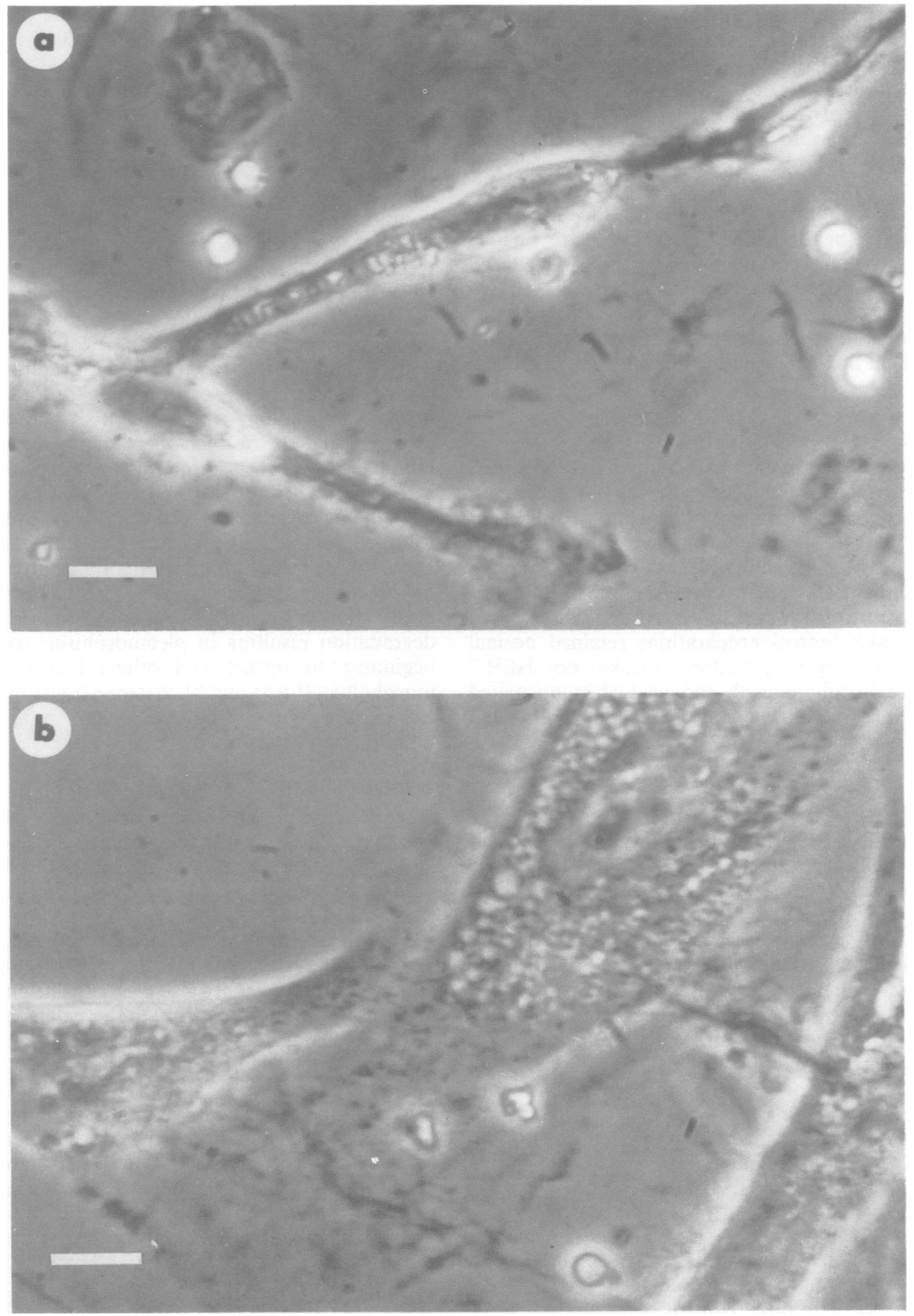

FIG 1 Phase-contrast micrographs of cells derived from normal rabbit testicular tissue after incubation for 48 with: (a) viable treponemes and (b) heated treponemes. Scale bar $=30 \mu \mathrm{m}$. 
In these experiments one additional chamber was inoculated with viable treponemes and incubated inverted so that the cultured cells were on the top. After 48 hours most of the treponemes had settled to the bottom of the chamber and relatively few organisms were attached to the cultured cells. After 48 hours the morphology of the testicular cells was unchanged and appeared identical to the cells incubated with heated treponemes, the high-speed supernatant, or the MEM. Retention of treponemal motility in chambers incubated in the inverted and upright positions was identical. Thus, the altered cellular morphology was attributed to attachment of organisms rather than to the release of some soluble treponemal factor during incubation.

HUMAN FORESKIN AND HEP-2 CELLS

In identical experiments with human foreskin cells and HEP-2 cells incubated with viable treponemes, large numbers of organisms attached to both types of cells; after 48 hours morphological damage was indicated by loss of cellular detail, rounding of cells, and cellular detachment from the substratum (fig 2a). In contrast, however, both types of cells exposed to the three control preparations retained normal morphology (fig 2b). Neither foreskin nor HEP-2 cells were morphologically damaged when inoculated with viable organisms and incubated in inverted chambers.

\section{CARDIAC MUSCLE CELLS}

These cultured cells retain the ability to beat in vitro for 2-3 weeks and numerous groups of 5-10 cells beat synchronously. Viable $T$ pallidum disrupted the cellbeating process; the cardiac cells beat spasmodically with loss of synchrony and then stopped beating altogether. In preliminary experiments, beating stopped within 14 hours in the presence of $4 \times 10^{8}$ treponemes $/ \mathrm{ml}$ and within 39 hours in the presence of $4 \times 10^{7}$ treponemes $/ \mathrm{ml}$. With lower concentrations of treponemes or with MEM alone, beating continued for $\mathbf{7 0}$ hours, when the experiments were terminated.

Morphological damage was assessed by incubating the cardiac cells with viable treponemes $\left(9 \times 10^{7}\right.$ to $2 \times 10^{8}$ organisms $/ \mathrm{ml}$ ), heated treponemes, the high-speed supernatant, or MEM. As with other cell types viable, but not heated, treponemes immediately attached to the cardiac cells. After 48 hours the viable preparation severely damaged the cultured cells (fig 3a). The three control preparations, however, showed normal morphology. Fig $3 \mathrm{~b}$ shows cardiac cells incubated for $\mathbf{4 8}$ hours in the presence of heated treponemes. In these experiments beating of the cells stopped in the presence of the viable organisms well before morphological damage was evident.

SKELETAL MUSCLE CELLS

These muscle cells are readily differentiated from the background fibroblasts. Individual myoblasts coalesce to form characteristic long myotubes containing multiple nuclei. These cells were incubated with viable treponemes, heated of treponemes, the high-speed supernatant, or MEM. The viable, but not the heated, organisms attached to the muscle cells and to the background fibroblasts. Attachment resulted in morphological destruction.

By scanning electron microscopy cultured cells $\stackrel{\infty}{=}$ exposed to the three control preparations showed ${ }_{\infty}$ normal morphology after $\mathbf{4 8}$ hours' incubation. In cells exposed to the high-speed supernatant for $48 \vec{\overrightarrow{ }}$ hours the myotubes were elongated and character- $\frac{}{3}$ istically grew on top of the background fibroblasts (fig 4). The myotube surface was smooth with gently $\mathbb{D}$ rounded contours; the background fibroblasts were apparent beneath this portion of the myotube. In muscle cells exposed to viable treponemes for 24 hours the myotubes showed various stages of $\vec{\oplus}$ degradation resulting in pleomorphism; some were $N$ beginning to retract and others had a rounded $\square$ morphology (fig 5a and b). After 48 hours the muscle cell (at the right of the micrograph) is apparently retracting and that on the left is almost completely rounded and contains numerous surface projections $\mathbb{D}$ not present on cells in control preparations. At this $\underset{\vec{F}}{\overrightarrow{7}}$ magnification treponemes can be seen. Initially, large $\frac{\circ}{3}$ numbers of actively motile organisms attached along $\vec{\partial}$ the full length of the myotubes. Morphological damage to the muscle cells resulted in detachment of treponemes.

The treponemes also damaged the background fibroblasts, causing irregular holes (fig 6); numerous attached treponemes are also evident. The underlying substratum can be seen through these damaged areas of the fibroblasts. In the three control preparations, 9 the morphology of the background fibroblasts was $\frac{7}{0}$ unaltered.

One further notable observation was the presence $\mathcal{O}^{\circ}$ of a few treponemes attached to the cultured muscle cells which were exposed to the high-speed super- $O$ natant. These treponemes were either apparently not $\omega$ pelleted during the high-speed centrifugation or inadvertently resuspended during the removal of theco supernatant. In fig 7 a portion of a myotube is shown $₫$ with an attached "half treponeme" (arrow), which $\stackrel{\infty}{+}$ appears to be penetrating into the myotube. This $\underset{T}{0}$

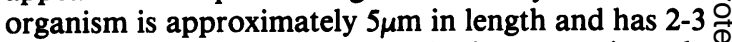
spirals; the other (arrowhead) is approximately $20 \mu \mathrm{m}$ in length and has 12-14 spirals. 

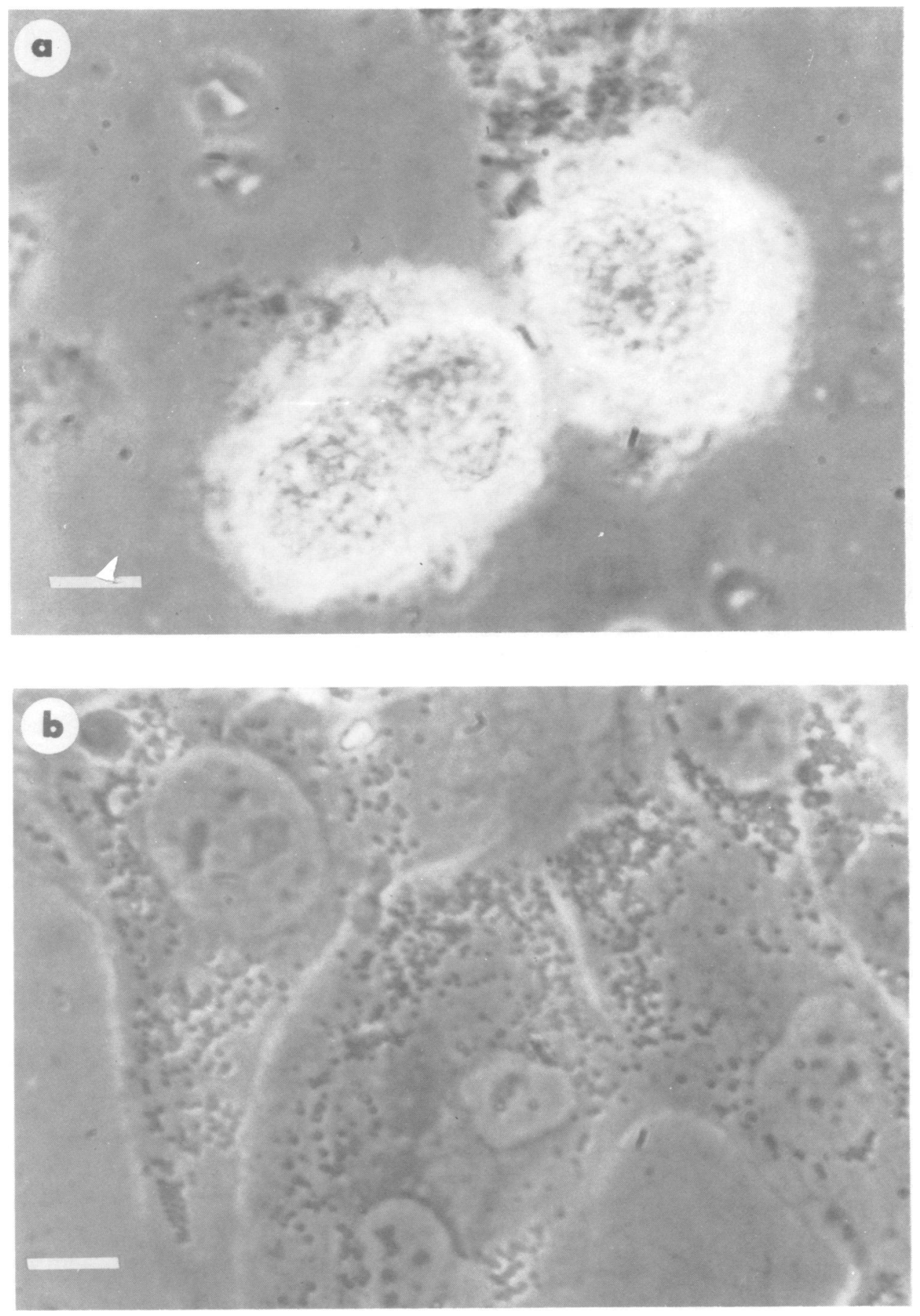

FIG 2 Phase-contrast micrographs of HEP-2 cells after incubation for 48 with: (a) viable treponemes and (b) MEM. Scale bar $=30 \mu \mathrm{m}$. 
$T$ J Fitzgerald, L A Repesh, and S G Oakes

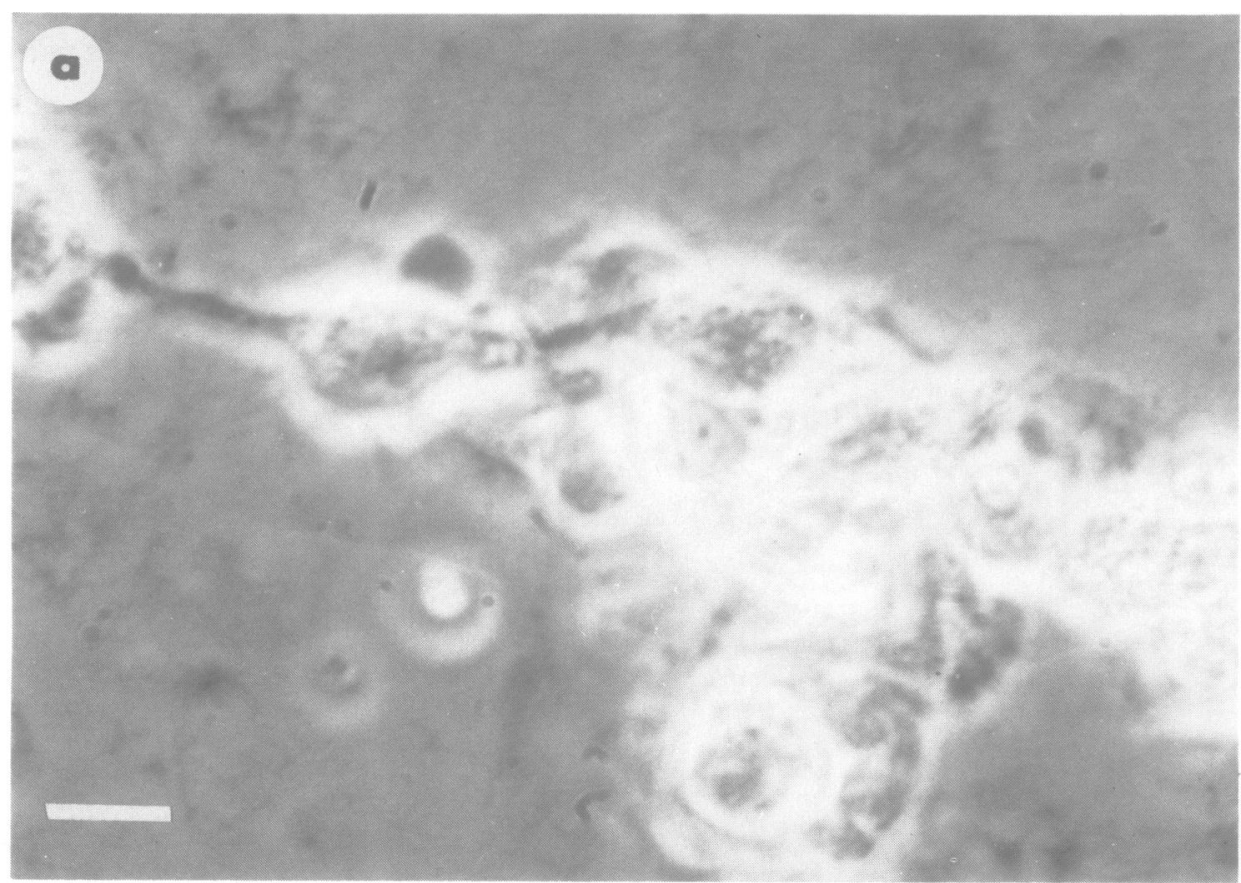

$\frac{c}{\infty}$

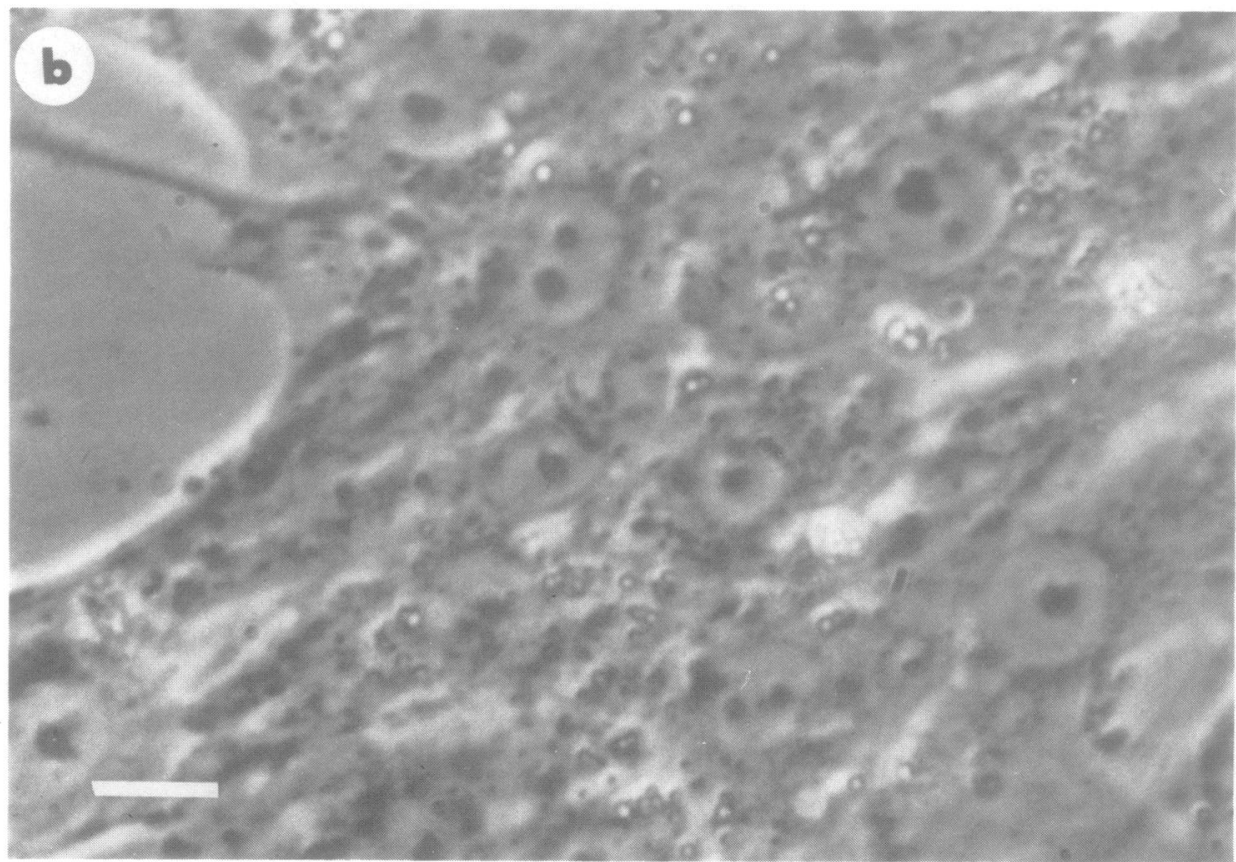

FIG 3 Phase-contrast micrographs of rat cardiac muscle cells after incubation for 48 with: (a) viable treponemes and (b) heated treponemes. Scale bar $=30 \mu \mathrm{m}$. 


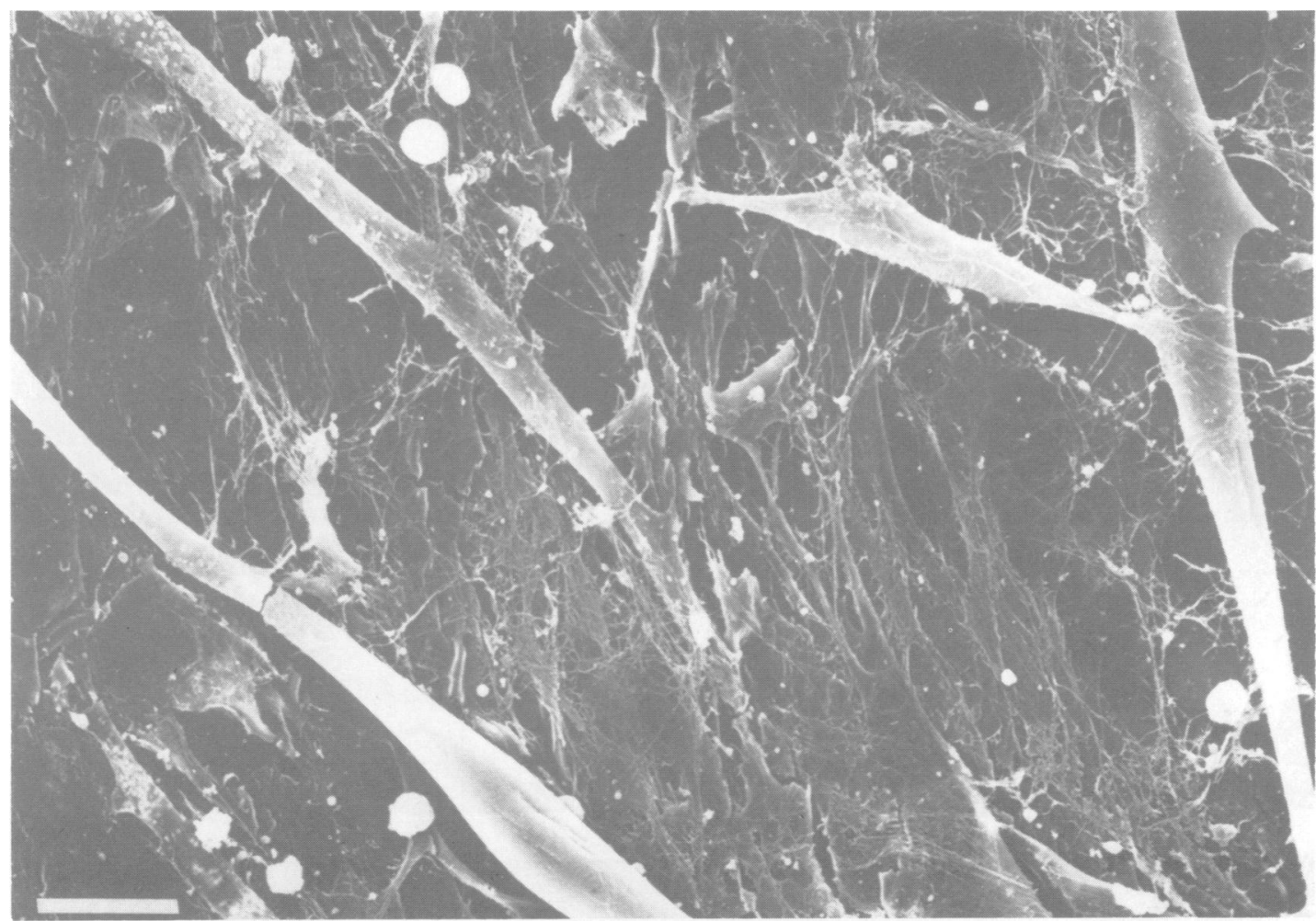

FIG 4 Scanning electron micrograph of rat skeletal muscle cells after incubation for $48 h$ with the high-speed supernatant. Individual myoblasts coalesced to form elongated myotubes. Scale bar $=30 \mu \mathrm{m}$.

\section{Discussion}

Repesh et al ${ }^{1011}$ reported that $T$ pallidum disrupted the integrity of cultured cells from dorsal-root ganglia. The present findings extend treponememediated tissue culture damage to five other cell types. Many other studies of $T$ pallidum-cultured cell interaction have been performed. ${ }^{8}$ Cellular damage had not been previously reported, probably because lower initial inocula ranging from $1 \times 10^{5}$ to $5 \times 10^{7}$ organisms $/ \mathrm{ml}$ were used. In this study the inocula ranged from $9 \times 10^{7}$ to $2 \times 10^{8}$ organisms $/ \mathrm{ml}$. These concentrations are within physiological levels. After dermal inoculation of rabbits, clinical manifestations first become apparent when treponemes reach a critical concentration of $1 \times 10^{7}$ organisms. $^{2}$ With a generation time of 30 hours approximately $2.4 \times 10^{8}$ organisms should be present after five days. Since virtually every cultured cell had attached treponemes, damage was uniformly evident. Some cells, however, were more quickly damaged than others; furthermore, damage resulted in detachment of treponemes.
These studies were performed with cultured cells from rabbit, human, and rat tissues. $T$ pallidum infection of rabbits mimics infection of man. In contrast, infection of rats produces minimal tissue response and asymptomatic infection. ${ }^{2}$ Although overt clinical lesions usually do not occur, and treponemes are difficult to visualise in the tissues, their presence can be demonstrated by transfer of rat tissue to rabbits with the subsequent development of lesions. The interaction of $T$ pallidum with cultured cells from rabbit and human tissue is comparable to that for other cells derived from rat, mouse, dog, monkey, and pig. ${ }^{8}$ Similar numbers of organisms attached, and attachment extended survival. Thus, the basis for minimal treponemal infection of these animals is probably not associated with innate differences in tissues. More likely, the lack of symptomatic infection indicates innate differences in serum factors or in enhanced host humoral or cellular immune responses. Thus, insights into the pathogenesis of $T$ pallidum should result from studies of cultured cells derived from different species of animals. 

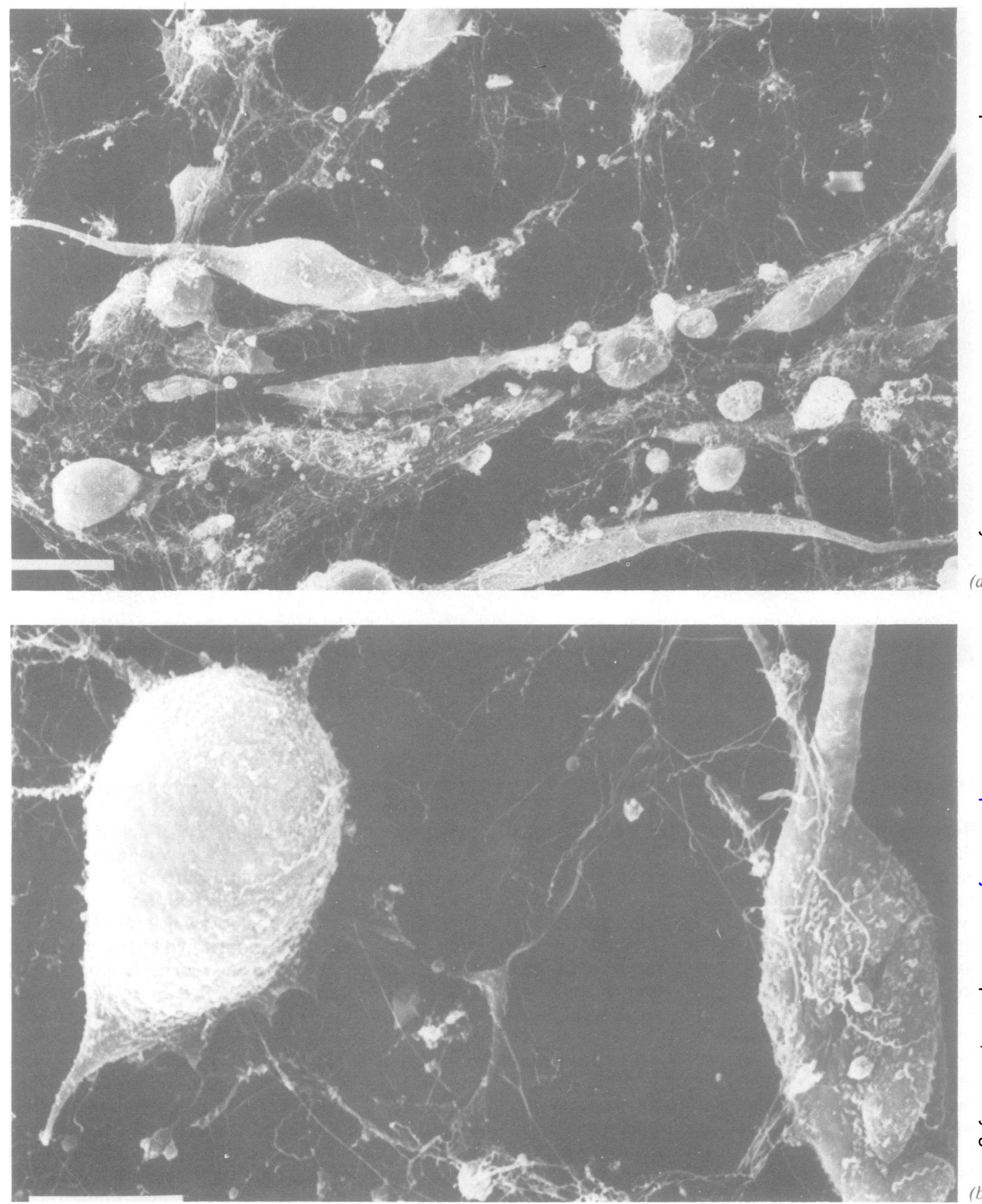

FIG 5 Scanning electron micrographs of rat skeletal muscle cells after incubation for $24 \mathrm{~h}$ with viable treponemes. (a) The myotubes exhibit various stages of degradation resulting in pleomorphism. (b) After $48 \mathrm{~h}$ more damage is apparent; the left cell is almost completely rounded and contains surface projections not observed in control preparations. Scale bar $=30 \mu \mathrm{m}$ (a) and $10 \mu \mathrm{m}$ (b). 


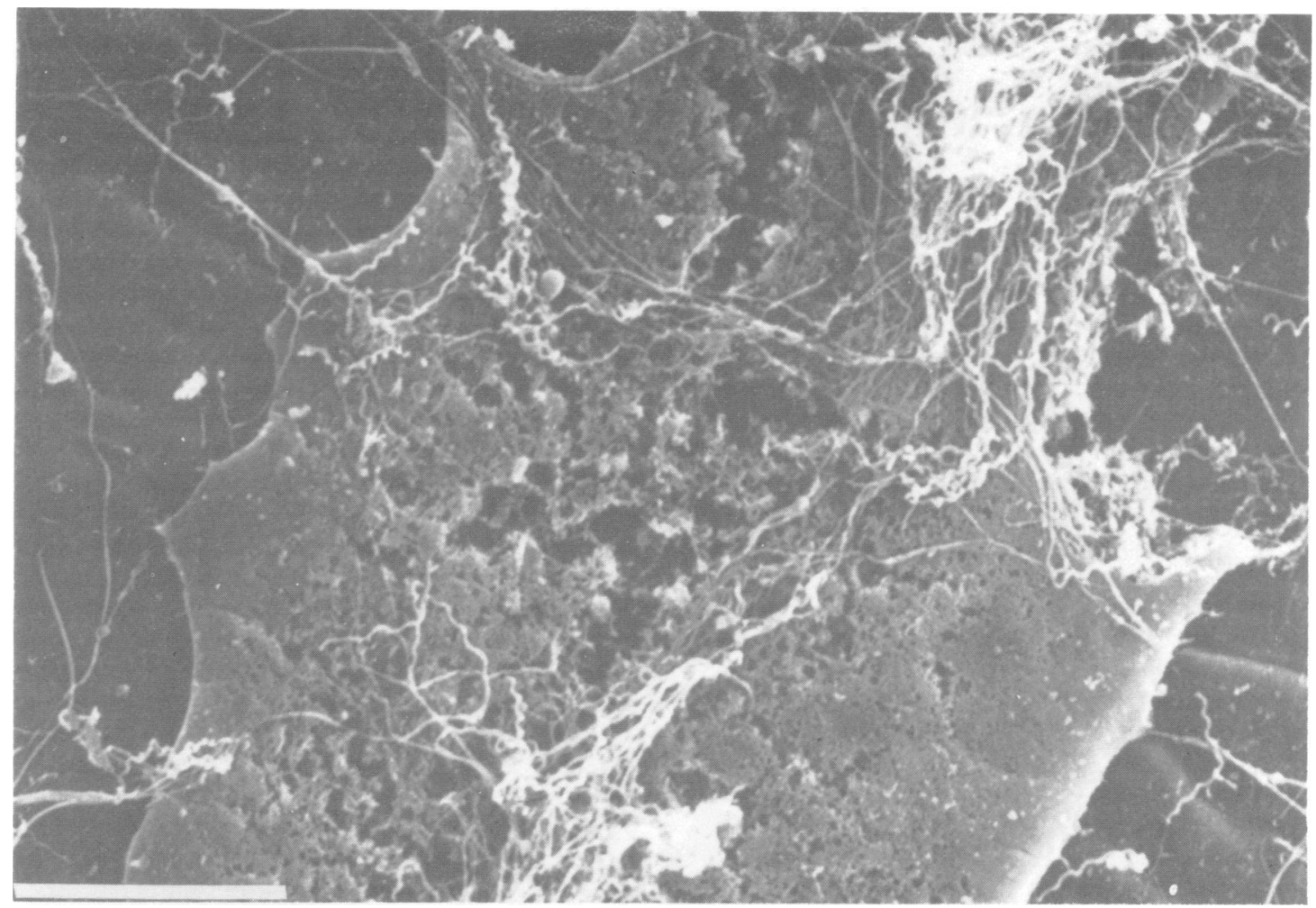

FIG 6 Scanning electron micrograph of the background fibroblasts within the cultured skeletal muscle cell preparation after incubation for $48 \mathrm{~h}$ with viable treponemes. Irregular holes are apparent at the surface of this group of fibroblasts. Scale bar $=10 \mu \mathrm{m}$.

Disruption of cultured cells was mediated through the attachment of viable treponemes, which had been pelleted by centrifugation and then resuspended in fresh MEM. Heat-inactivated organisms that failed to attach did not damage the cells. Soluble factors were not involved. The high-speed supernatant that remains after pelleting the organisms contains soluble treponemal, soluble inflammatory, and soluble testicular components; it did not affect the tissue culture cells. Furthermore, when chambers were inoculated with viable $T$ pallidum and incubated inverted with the cultured cells uppermost, no cell damage was observed indicating that soluble factors released by the organisms during incubation were not responsible for the damage. Thus, the initial cellular lesion probably occurs at the point of attachment of treponemes. Some type of treponemal toxic activity may exert a membrane lytic effect.

$T$ pallidum possesses the ability to penetrate cells, as shown by the partial entry of the organism into the muscle cells. It is well established that treponemes are found intracellularly in relatively low numbers in vivo within a variety of host cells ${ }^{15-18}$ and in vitro in cultured rabbit testicular cells. ${ }^{5}$ Penetration of treponemes may be related to their membrane lytic action resulting in small holes in the membrane. If few organisms attach, cells may be able to repair the damage. If large numbers of organisms attach, the holes may accumulate to the point of pronounced membrane damage, thereby explaining morphological disruption of the cultured cells.

Treponemes cause dysfunction of the beating of cardiac muscle cells; this occurred before morphological damage and may have reflected the early events associated with cellular disruption. A similar observation was reported with the cultured nerve cells, ${ }^{10} 11$ in which $T$ pallidum initially caused dysfunction as indicated by their loss of ability to respond to electrophysiological stimuli; this was followed by cellular disruption.

Other reports have described damage to tissue culture cells by bacteria. Portnoy et al ${ }^{19}$ found that Yersinia enterocolitica initially attached to HEP-2 cells, then became intracellular. Within 90 minutes of 


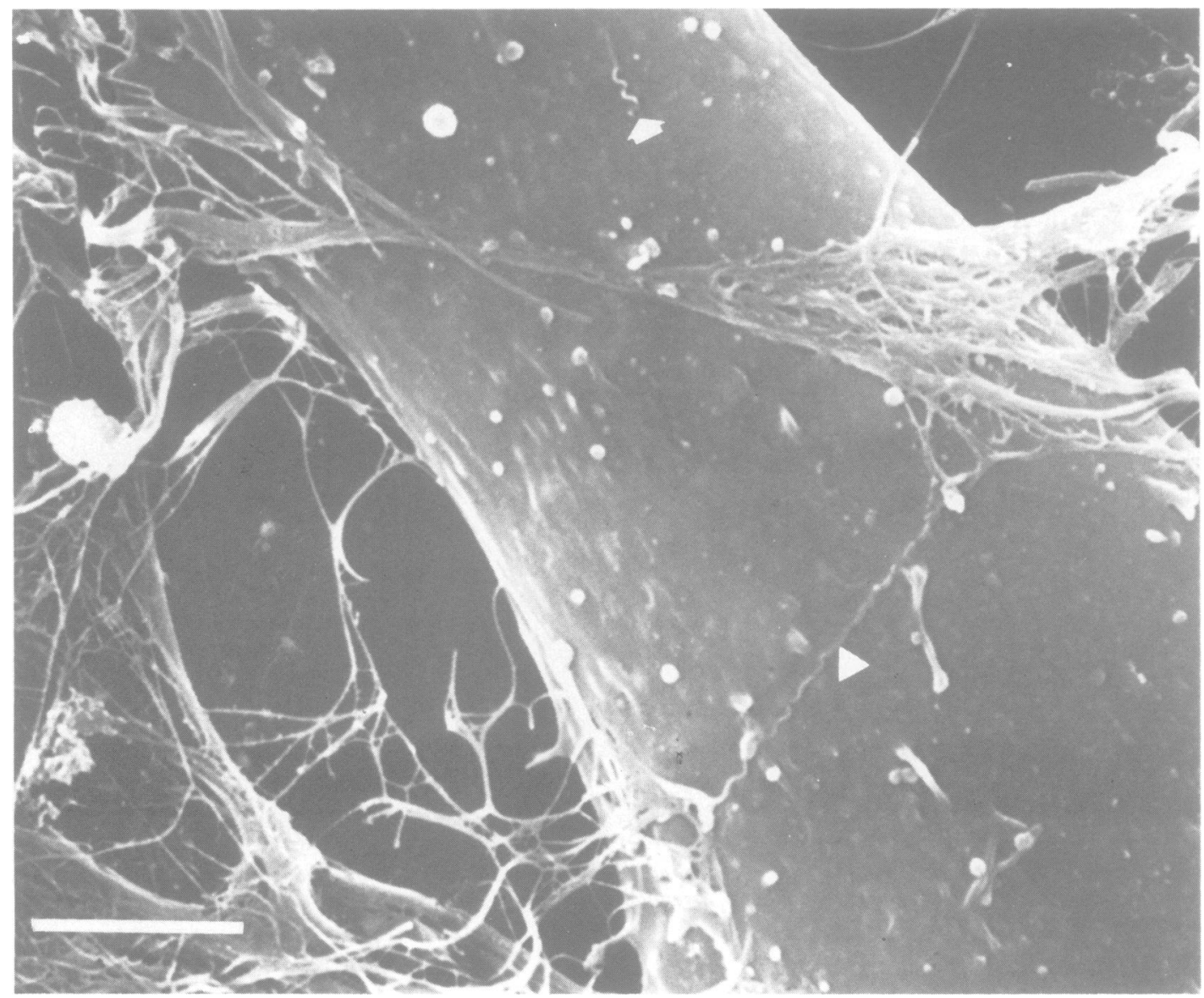

FIG 7 Scanning electron micrograph of a portion of a skeletal muscle myotube showing a half-treponeme (arrow). Note the normal size treponeme (arrowhead). Scale bar $=5 \mu \mathrm{m}$.

inoculation the cultured cells detached from the growth substratum. This toxic activity required the attachment of the bacteria to the HEP-2 cells. Neither a cell-free supernatant nor a membranefiltered sonicate of the bacteria was detrimental. Guerrant $e t a^{20}$ reported that the enterotoxins of both Escherichia coli and Vibrio cholerae morphologically altered Chinese hamster ovary cells within 24 hours. They suggested that cyclic adenosine monophosphate (AMP) mediated the changes, which included cell elongation, polarisation, and loss of knob-like projections. Vicari et $a^{21}$ demonstrated the detrimental effects of Shigella dysenteriae after attachment to cultured cells. Others ${ }^{22-24}$ have confirmed and extended these findings. The Shigella cytotoxin specifically inhibited protein synthesis within HeLa cells and human embryonic intestinal cells. This resulted in rapid detachment of the cultured cells from the growth substratum.

Treponemal damage to tissue culture cells may explain some of the clinical manifestations of syphilis; at least two mechanisms are concerned in potential tissue pathology. Firstly, the organisms $N$ may be relatively innocuous, and damage could result from host inflammatory reactions and from host defence mechanisms involved in clearance of the ${ }^{\mathrm{\omega}}$ organisms. ${ }^{3}$ This mechanism is supported by the rebound phenomenon in rabbits infected dermallye

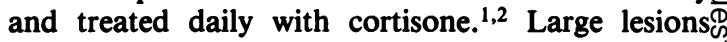
develop atypically with minimal cellular infiltration and become greatly intensified a few days afterwithdrawal of the cortisone. The latter stimulates the host defences and produces cellular infiltration. The subsequent degradation and clearance of organisms $\triangle$ 
may then explain the intensification of the lesions. Secondly, specific treponemal components may degrade various tissues. In the above example, rabbit host defences are minimised before cortisone withdrawal, and large lesions develop in the absence of the usual cellular infiltration. If the in-vitro findings presented in this paper can be extended to infection in vivo toxic activities of $T$ pallidum could explain the histopathology of syphilis. In summary, both mechanisms of tissue pathology may be operative in syphilis.

We wish to acknowledge the efforts of Eileen Gannon, Bonnie Tyson, and Paul Lima in providing excellent technical assistance, Carolyn Gabriel for developing and processing the photomicrographs, and Dr Robert Pozos, Department of Physiology, University of Minnesota, Duluth, for providing the cultured cardiac cells and the cultured skeletal muscle cells. This research was supported by Public Health Service National Institute of Allergy and Infectious Diseases grant AI 16585, Minnesota Medical Foundation grant DMRF 53-80, and the University of Minnesota Graduate School grant 464-0325-4909.

\section{References}

1. Turner TB. Syphilis and the treponematoses. In: Mudd S (ed). Infectious Agents and Host Reactions. Philadelphia: W B Sanders, 1970:346-90.

2. Turner TB, Hollander DH. Biology of the treponematoses. WHO Monograph Series No 35, 1957.

3. Hardy PJ, Graham DH, Nell EE, Dannenberg AM. Macrophages in immunity to syphilis: suppressive effect of concurrent infection with Mycobacterium bovis BCG on the development of syphilitic lesions and growth of Treponema pallidum in tuberculin-positive rabbits. Infect Immun 1979; 26: 751-63.

4. Wright MI. Exploratory studies in tissue culture of $T$ pallidum. Proceedings of the XII International Congress of Dermatology 1962; 2:844-87.

5. Fitzgerald TJ, Miller JN, Sykes JA. Treponema pallidum (Nichols strain) in tissue cultures: cellular attachment, entry, and survival. Infect Immun 1975; 11:1133-40.
6. Fitzgerald TJ, Johnson RC, Miller JN, Sykes JA. Characterization of the attachment of Treponema pallidum (Nichols strain) to cultured mammalian cells and the potential relationship of attachment to pathogenicity. Infect Immun 1977; 18:467-78.

7. Fitzgerald TJ, Miller JN, Sykes JA, Johnson RC. Tissue culture and Treponema pallidum. In: Johnson RC (ed). The Biology of Parasitic Spirochetes. New York: Academic Press, 1976:57-64

8. Fitzgerald TJ. Pathogenesis and immunology of Treponema pallidum. Ann Rev Microbiol 1981;35:29-54.

9. Fitzgerald TJ, Cleveland P, Johnson RC, Miller JN, Sykes JA Scanning electron microscopy of Treponema pallidum (Nichols strain) attached to cultured mammalian cells. $J$ Bacteriol 177; 130: 1333-44.

10. Oakes SG, Repesh LA, Pozos RS, Fitzgerald TJ. Electrophysiologic dysfunction and cellular disruption of sensory neurons during incubation with Treponema pallidum. $J$ Neuropathol Exp Neurol 1981 (in press).

11. Repesh LA, Fitzgerald TJ, Oakes SG, Pozos RS. Scanning electron microscopy of the attachment of Treponema pallidum to nerve cells in vitro. J Neuropathol Exp Neurol 1981 (in press).

12. Sykes JA, Moore EB. A simple tissue culture chamber. Tex Rep Biol Med 1960; 18:288-97.

13. Marvin WJ, Robinson RB, Hermsmeyer K. Correlation of function and morphology of neonatal rat and embryonic chick cultured cardiac and vascular muscle cells. Circ Res 1979; 45: 528-39.

14. Fischbach GD. Synapse formation between dissociated nerve and muscle cells in low-density cell cultures. Dev Biol 1972; 28:407-29.

15. Azar HA, Pham TD, Kurban AK. An electron microscopic study of a syphilitic chancre. Arch Pathol 1970;90: 143-50.

16. Lauderdale V, Goldman JN. Serial' ultrathin sectioning demonstrating the intracellularity of $T$ pallidum. $B r J$ Vener Dis 1972; 48:87-99.

17. Sykes JA, Miller JN. Intracellular location of Treponema pallidum (Nichols strain) in the rabbit testis. Infect Immun 1971;4:307-14.

18. Sykes JA, Miller JN, Kalan AJ. Treponema pallidum within cells of a primary chancre from a human female. $\mathrm{Br} J$ Vener Dis 1974; 50:40-4.

19. Portnoy DA, Moseley SL, Falkow S. Characterization of plasmids and plasmid-associated determinants of Yersinia enterocolitica pathogenesis. Infect Immun 1981;31:775-82.

20. Guerrant RL, Brunton LL, Schnaitman TC, Rebhun LI, Gelman AG. Cyclic adenosine monophosphate and alteration of Chinese hamster ovary cell morphology: a rapid sensitive invitro assay for the enterotoxins of Vibrio cholerae and Escherichia coli. Infect Immun 1974; 10:320-7.

21. Vicari G, Olitzki AL, Olitzki A. The action of thermolabile toxin of Shigella dysenteriae on cells cultivated in vitro. $\mathrm{Br} J$ Exp Pathol 1960;41: 179-89.

22. Brown JE, Rottman SW, Doctor BP. Inhibition of protein synthesis in intact HeLa cells by Shigella dysenteriae 1 toxin. Infect Immun 1980; 29:98-107.

23. Keusch FT. Pathogenesis of shigella diarrhea. III Effects of shigella enterotoxin in cell culture. Trans N Y Acad Sci 1973; 35: $51-8$.

24. Olsnes S, Eikled K. Isolation and characterization of Shigella shigae cytotoxin. J Biol Chem 1980; 225:284-9. 